Synthesis, part of a Special Feature on Public policies and management of rural forests: lasting alliance or fool's dialogue?

\title{
Forests as Patrimonies? From Theory to Tangible Processes at Various Scales
}

Genevieve Michon $^{1}$, Bruno Romagny $^{2}, \underline{\text { Laurent Auclair }}^{2}$, and $\underline{\text { Marc Deconchat }}^{3}$

\begin{abstract}
Among theoretical fields addressing the conceptualization of interrelationships between nature and society, patrimonial approaches remain relatively unexplored. Stressing the multiplication of local dynamics where elements of nature are redefined as "patrimonies" (ranging from local patrimonies to world heritage) by various social groups, this conceptual field tries to qualify these dynamics and their determiners to understand how they allow us to better address contemporary environmental challenges. Through a multidisciplinary approach in social sciences, centered on rural forests, we analyze the multiplication of patrimonial processes in forest development at various scales. First, we elaborate on the concept of patrimony and on patrimonial processes and present the current construction and dynamics of forest patrimonies. A crucial question concerns the links that form between the many spatial-temporal levels where these processes develop. Moreover, these patrimonial processes can be quite divergent, not only across scales from local to global, but also between "endogenous" (or bottom-up) and "exogenous" (or top-down) processes. We present two detailed examples in Morocco and Sumatra, where patrimonial constructions are developing simultaneously at various scales and through various actors who treat the forest in very different ways. Drawing from these examples, we discuss how and why the simultaneous development of different, often overlapping, patrimonial constructions along these scales allows collaboration or, conversely, can lead their holders into conflict. Lastly, we discuss the contribution of patrimonial concepts to resilience thinking and social-ecological systems theory.
\end{abstract}

Key Words: international policies; local forest management; patrimonial processes and approaches

\section{INTRODUCTION}

Among theoretical fields addressing the conceptualization of interrelationships between nature and society, patrimonial approaches (Barthélemy and Nieddu 2007, Calvo-Mendieta et al. 2011) remain relatively unexplored, at least at an international level and for English-speaking scholars.

Patrimonial approaches have traditionally been developed by scholars working in the fields of private law, architectural monuments, and culture. For a few decades now, patrimony and patrimonial processes have been redefined and appropriated as meaningful analytical categories by other human and social sciences such as sociology, anthropology, geography, or economics in order to highlight new trends in the relationship between societies and their "natures." Stressing the multiplication of local dynamics, where elements of nature are redefined as "patrimonies" by various social groups (from local communities to international agencies), this conceptual field tries to qualify these dynamics and their determiners and to understand how they address contemporary environmental challenges.

Our paper discusses the relevancy of these patrimonial concepts for analyzing the dynamics of forest-society relationships. We discuss both conceptual approaches and concrete patrimonial processes using the example of rural forests.

First, we elaborate on the concept of patrimony as first redefined by the work of Henry Ollagnon in the 1970-1980s, and further developed by other scholars in the social sciences. For Ollagnon, patrimony refers to "the compendium of all material and immaterial elements that help maintain and develop, by adaptation in an evolutionary context, the identity and autonomy of its holder, through time and space" (Ollagnon 1979). For Ollagnon's followers, the term also refers to "a set of material and symbolic elements which allow a human community to anchor itself in space and time" (Nieddu et al. 2009). Patrimony is also something that "binds people" (Micoud and Peroni 2000), it is therefore the expression of a peculiar type of social relationship integrating elements of natural and cultural environments. When it applies to nature, it also refers to a peculiar type of nature-society relationship.

As well as patrimony, we also elaborate on "patrimonialization of nature," which refers to processes of social, cultural, and political construction through which elements of nature are incorporated into a heritage at either local, national, or international levels. A crucial question concerns the links that form between the pluralities of spatial-temporal levels where these processes develop. We present the dimensions of forest patrimonies at various scales. Drawing from two contrasting examples, we then discuss how and why the simultaneous development of different, often overlapping, patrimonial constructions along these scales allows collaboration or, conversely, might bring their holders into conflict. Lastly, we discuss the contribution of patrimonial concepts to resilience thinking and social-ecological systems theory. 


\section{PATRIMONY: FROM SCHOLARS TO CONCRETE PROCESSES}

\section{Elements of Definition}

A patrimony is a set of material or immaterial elements to which are attached specific values and rights that are linked to a social group and are inherited and transmitted from one generation to the next. The term "patrimony" is equivalent to "heritage" in English. Even though "heritage" is more commonly used, we have chosen to keep the term "patrimony" in order to refer to the above-mentioned school of thought.

Patrimony was formerly considered to be merely a collection of objects and values managed for transmission (Handler 1987) and classical economic definitions still tend to reduce patrimony to capital (Vivien 2009). The definition proposed by Ollagnon emphasizes the idea of identity and autonomy of the holders, which incorporates social qualities and carries a sociopolitical overtone. This new concept of patrimony insists on intergenerational solidarity and collective action as inherent qualities of patrimony: patrimony is defined by elements that are "collectively selected as deserving to be transmitted from the past in order to find a value in the present" (Lazzarotti 2003). It also incorporates a high sense of intergenerational responsibility: inheriting, managing, and transmitting a patrimony is not only a right or a privilege, but also involves duties. Through these social perspectives, patrimony becomes a "tool for coordination" (Micoud 2000) or "a set of symbolic and material elements that confer spatial and temporal meaning to a human community" and is "devoted to the preservation and perpetuation of the social group to which it is attached" (Nieddu et al. 2009). In these perspectives, patrimony covers complex and diverse elements, situations, and processes and is clearly linked to special types of social relationships and social meaning. The concept has been appropriated by various disciplines in the social sciences: from law and economics to anthropology, sociology, ethnology, and geography. More recently, it has entered into debates and actions related to nature, biodiversity, and local knowledge (Cormier Salem et al. 2002, 2005), which has led to the emergence of a major theoretical field in natural resource management: patrimonial approaches.

For Ollagnon, the main concern of patrimonial approaches is what binds a patrimony and its holder(s) together, which implies that maintaining and developing someone's identity and autonomy constitutes an issue by itself. In a convergent analysis, Cormier-Salem has proposed relating the patrimonial status of a resource management system to three interdependent elements (Cormier-Salem et al. 2002):

- it holds a central place in the collective memory and the local perception of history;

- it is linked to protection and perpetuation, and therefore associated with a "conservation" objective, including conservation of social or cultural qualities;
- it plays a key role in the sustainability of local communities in time and space.

Patrimonial approaches in the field of social-environmental relationships, therefore, push purely environmental issues aside in order to focus on more social and political issues, considering that problems in resource management are mainly problems of relationships among actors about how to access and use resources. This somehow relates to common-property approaches (Ostrom 1990), but patrimonial approaches concentrate less on institutions and more on the various modes of resource appropriation (from management practices to rules), coordination, negotiation, and collective action for conflict resolution (Weber 1996). Scholarly approaches to patrimony also involve highlighting different processes of patrimonial construction-or destruction-for a given resource. Analyzing resource management through the lens of patrimony also involves demonstrating how a given resource and associated practices help maintain and develop the identity and autonomy of its holder.

\section{Patrimony in Action-Focused Approaches and Public Policies}

Patrimony and patrimonial approaches are not only exploratory concepts or theoretical positions mobilized by social sciences for the study of social-environmental relations. They also refer to tangible processes of social, cultural, and political construction in which related individuals, at various scales (local, national, international), select elements of their common past and designate them as essential for their collective future and, in doing so, form themselves into a community with specific sociopolitical objectives. Beyond the local scale, where it is easy to define the holders of a given patrimony, these processes encompass a set of action-focused approaches and public policies conducted in the name of collective and intergenerational interest in order to conserve elements (of architecture, culture, nature) seen as emblematic for a large - and often vague - community: nation, humanity. We call all these processes "patrimonialization." Patrimonialization of forest and biodiversity, and more recently of traditional knowledge, is becoming one of the main strategies for sustainable development and conservation policies.

Cormier-Salem and her colleagues, on their synthetic work on nature patrimonialization, have defined two broad categories of processes that relate to two different concepts of what a patrimony is and who defines it (Cormier-Salem et al. 2002, 2005). The first category concerns "exogenous" or top-down processes. Patrimonies are defined and instituted by states (reserves, parks) or at an international level (e.g., UNESCO's World Heritage concept, IUCN's "Red List of Endangered Species") in reference to complex issues linked to nature conservation. Patrimonies thus instituted focus on "endangered" elements of nature, from genes to ecosystems or landscapes and often discount local communities, or, at 
least, restrict their activities and access rights. The second category refers to "endogenous," or bottom-up, dynamics. It includes the various processes in which local communities are the main actors, and local interests the main drivers of a patrimonial construction that often holds loose reference to conservation. These processes are grounded in a collective attachment to significant elements that relate wholly to local histories and representations of nature-society relationships and that range from tree species, animal species, or agricultural products to sacred forests, cultural landscapes, or ritual ceremonies. Whereas exogenous patrimonializations aim to preserve the ecological integrity of ecosystems, these local patrimonial processes target social sustainability, strengthening of access to resources in time and space, social-ecological resilience, and adaptability.

These two categories often mix, combine, superimpose or overlap each other in the real world of patrimonialization, as we will show in the next section, with processes developing at different scales, sometimes simultaneously, and either independently from each other, or in an interdependent way.

\section{CONSTRUCTING FOREST PATRIMONIES AT VARIOUS SCALES: REINFORCEMENT OR CONFLICT?}

Whether at a local, regional, or national level, the patrimonial dimension of forests is an essential key to sustainability: as trees' life cycles largely exceed one human generation, forest sustainability as a social-ecological system (Liu et al. 2007) depends on long-term transmission of forest-related knowledge, practices, and rules. Up to the beginning of the 1980s, this patrimonial dimension was related either to local communities (forest constituting the heritage of a community, forming its resource base and its identity) or to states and nations (with national forest domains). Today, forest patrimonies develop mainly and simultaneously at the global level, with the notion of "world heritage," and at integrated local scales, from local communities to regions, through various processes of collective requalification of forest spaces and resources.

\section{Forest "Communities" and Their Patrimonies, from Local to Global}

At the family or local community level, the construction of domestic forests (Michon et al. 2007) as the central patrimonial element of local livelihoods has evolved with the history of the human group to which the forests are attached, as documented for the family forests in French Gascogny (Sourdril 2008), the Agdal and the argan forests of Morocco (Auclair et al. 2010, Simenel 2010), or the agroforests of Indonesia (Michon et al. 2000). Aside from sustaining local livelihoods on a day-to-day basis and securing access to and use of local resources in time and space through locally defined and collectively accepted rules, this domestic forest patrimony embodies shared property, tradition, and memory as well as intergenerational solidarity and interdependence. It constitutes the material and symbolic foundation of lineages and communities, and its management transcends the responsibility of its living holders. Transmitting this patrimony from one generation to the next, as well as the values, status, and rights attached to it, constitutes the warrant of economic and social sustainability. In this sense, patrimony relates to resilience, as Auclair et al. (2011) have discussed in their analysis of Agdal forests in the Moroccan High Atlas Mountains.

The construction of national forest patrimonies is also rooted in a nation's history, with forests being perceived by ruling elites as a strategic space, control of which is essential for the state's construction (Perlin 1997, Doornbos et al. 2000, Zerner 2000). This patrimonial vision of forest management at the highest level of the state incorporates concerns for either using forest resources for development or maintaining forest integrity and quality over the long term. It evolved early in Europe, with the establishment of a specific legal, administrative, and technical regulatory framework for state forests (Fay and Michon 2005), acceptability of which relied on the establishment of a social contract presenting the forest as a public good: whereas the holder of this forest patrimony is not the state, but rather the community of "citizens," the forest has to be managed with the long-term perspective benefitting this community. Most national forest patrimonies around the world still refer to this rhetoric, where the state is the legitimate warrant of the patrimony's integrity for all the citizens. Especially in southern countries, the historical construction of national forest patrimonies involved important territorial reorganization, which was more often than not used to launch economic development projects conflicting with the logistics of local forest patrimonies, as is clearly shown by the delineation of state forests in Indonesia since the late 1970s. The control of forest lands in the outer islands, and their classification as "production" and "conversion" forests, first boosted timber mining by international firms and then allowed an outstanding expansion of capitalistic agriculture (particularly oil palm industrial estates), which contributed to Indonesia's high rates of deforestation (Gillis 1998) and totally erased highly original local forest patrimonies (Fried 2000).

The emergence of global environmental issues has raised international awareness about the world's forests, not only as important elements of environmental regulation, but also as a unique patrimony common to all humans, far greater than the patrimony of nations or local communities living on forest territories. This extension of the notion of patrimony at a planetary scale, instituted by UNESCO in 1972 with the recognition of "world heritage," is built by reference to scientific, historical, or aesthetic values that are often specific to western culture but are established as universal. At the world level, forests in general and tropical forests in particular fall within this scope as they constitute "irreplaceable systems" of 
"outstanding universal value" (UNESCO 1972), which have been inherited from the past and need to be conserved and transmitted to future generations, and therefore, deserve a particular collective effort for their protection and sustainable management. The constitution of the world's forests as a collective patrimony at the scale of humankind was carried out by a variety of actors, from national scientists to international development institutions and conservation agencies (Smouts 2001). Even though international debates about forests did not translate into a specific convention, the management of this international forest patrimony is strongly influenced by the International Convention on Biodiversity (1992) and the Kyoto protocol (1997), and this has important consequences. The reference to ecological integrity, megabiodiversity, or emblematic spaces discards "ordinary" forests modified by man, even if local cultures and knowledge are sometimes integrated into these global forest patrimonies.

\section{Forest Patrimonies and Their "Communities"}

Moving along these scales from local to international, patrimonial construction processes, objectives, and meanings, actors, and beneficiaries differ rather radically, which can explain why representations and successes of patrimonies are different and may be conflicting.

Along the scales, there is a movement from direct proximity of the patrimony's holders with forest resources, places, and history, as well as an economic, symbolic, and cultural attachment to them, to a geographical and cultural distance coupled with an environmentalist justification with universal pretention. Patrimonial movements at the local scale relate to the local community's identity, resource base strengthening, social sustainability as well as land and political rights. Local patrimonialization movements also focus on a holistic socialecological relationship more than on specific objects. Moving to higher scales, patrimonial constructions relate more to global territorial and resource control or to preservation of the richness and functional integrity of forest ecosystems. They target primarily "objects" (species, spaces, landscapes, ecosystems) and qualify them from a naturalistic (in the sense given by Descola (2005), considering nature and humanity as two separate and distinct entities) perspective. Instead of connecting these objects to the actual practices that have created or that maintain them, they establish a protection system that inhibits this social-ecological relationship, which may endanger the success of the patrimonial process (see below).

\section{OVERLAPPING FOREST PATRIMONIALIZATION: SCALING UP OR DOWN?}

New patrimonial constructions or deconstructions often superimpose on already existing patrimonies. As they mobilize specific institutions, norms, knowledge, practices, and rules, and favor specific actors, they may entail unsteadiness between already existing patrimonial identities and the stakes incorporated into the new patrimonial dynamics.

\section{Constructing Global Patrimonies at the Expense of Domestic Patrimonies? The Argan Forest in Morocco}

The argan forest in the southwest of Morocco is a unique ecosystem dominated by Argania spinosa, an endemic species, probably the most original tree species in northern Africa. It covers about 800,000 ha and supports five million people. Argan trees and forests are presently considered by national forest services and environmentalists at national and international levels as "natural riches" threatened by local farmers.

Inhabited and used for centuries, the argan forest is far from being "natural." At a local scale, the elements of the argan patrimony are social as well as ecological. The argan tree constitutes the support of a variety of spaces managed for grain culture, pastoralism, or argan oil production (Simenel 2010). These different spaces are managed by a complex set of practices and rules distributing access and use rights of the different stakeholders through time and space (Simenel et al. 2009). This articulation among families, lineages, and tribes, among beneficiaries of fruit harvesting, field cultivation, or grazing, relates to a strong historical dimension that binds the history of people to that of places and trees (Simenel 2010), which constructs the argan forest as a multidimensional domestic patrimony (Auclair and Michon 2009). This patrimonial dimension, which incorporates argan trees and lands as well as knowledge and adaptive practices, religious beliefs, and customary rights transmitted from one generation to another has largely been ignored by forest administration services as well as by valuation or conservation projects that have attached other patrimonial values to the argan forest.

At the state level, the argan forest is considered to be a major "natural" patrimony. It is incorporated into the national forest domain, administered and managed by national forest services who consider farmers as the main threat to the forest. Management measures are driven by the need for income production and the perception of the whole argan forest as "degraded." Income generation is provided by charcoal production, which involves clearcutting of large areas. Rehabilitation is ensured through total prohibition of grazing and harvesting for long periods ( $>10$ years). This national vision of patrimony conflicts with local systems based on sitespecific practices and regulations and on the integration of pastoralism and grain culture in well-defined forest spaces.

The argan tree (a botanical curiosity, a sort of "living fossil" from the Tertiary Era, endemic to Morocco) and the argan forest (the most biodiverse ecosystem close to the Sahara) have attracted international patrimonial attention. The argan forest is presented as unique wilderness, which legitimizes its inclusion in the world heritage. It is considered "endangered" because of demographic expansion and destructive grazing 
practices carried out by local farmers, which also serves to legitimize its protection under the international UNESCO regime of Biosphere Reserves and restricts-at least in theory -farmers' practices. Moreover, over the last 15 years, the international development community has initiated another patrimonial movement: commercial promotion of argan oil as a unique product, a blend of natural heritage and a legacy of Berber women's "secret knowledge." Argan oil is now a renowned product in international cosmetic markets, with a well-established processing and marketing chain.

This double patrimonial construction displaces argan forest patrimonies from the local scale, where they are defined and managed as a multipurpose domestic forest, to higher scales, where oil production and biodiversity conservation constitute the main patrimonial dimensions. It distorts the socialecological nature of local patrimonies (Simenel et al. 2009) by disassociating the material dimension of the patrimony (the ecosystem) from associated practices. It puts forward a naturalist vision of the argan forest ("natural," "unique," "endangered") that altogether, and in a rather contradictory movement, negates the existence of long-standing local management and domestication and disqualifies them. Through this global patrimonial qualification, the international community provides renewed argument for the exclusion of local populations, which reinforces the legitimacy of the state in argan forest management. The focus on argan oil production in a patrimonial development project erases the complexity of the relationship linking the various elements of local forest patrimonies (the argan oil, but also goat, honey, and grain production, medicinal plants, arganwood handicrafts, etc.) for the variety of their traditional holders.

Instead of reinforcing the identity of the argan forest as a social-ecological patrimony managed by local practices that have proven their long-term success, these new patrimonial constructions therefore transform it into a global environmental object managed by international and national experts in ecology, conservation, marketing, and product development, thus dispossessing local communities: local people are tolerated in this patrimonial forest, but their freedom of action and decision is taken from them and given to these "experts" who determine what are the "good practices." Negative consequences of this dispossession of local managers are to be expected.

Field observations (Auclair et al., unpublished manuscript) show, however, the resilience and adaptability of local forms of management. They also show that the different patrimonial categories established at local, national, and international levels necessarily intertwine and find their specific niche along the territory. Cultivated forests near villages constitute the main element of domestic and local patrimonies. Decisions about these village forests involve the local population and their representatives, the local authority, and foresters. Beyond these inhabited areas, the argan forest is managed in a conventional way by the State Forest Administration under the supervision of the Ministry of Forestry. Further away, forests that are less accessible and richer in biodiversity have become the main target of the world heritage conservation process, and have been integrated into the central area of the Biosphere Reserve.

\section{Constructing Conflicting Patrimonial Claims in Tropical Rainforest: the Uncertain Fate of Indonesian Agroforests in the South of Sumatra}

Agroforests result from the reconstruction of local forests through the introduction of economic tree species into swidden cultivation cycles (Michon and de Foresta 1999). In the south of Sumatra, local people have established complex forest systems over the last century or so that are based on the cultivation of a resin-producing tree (the damar, Shorea javanica). The construction of damar agroforests by local people constitutes an interesting process of patrimony establishment on formerly common lands: in planting damar trees on their swiddens, local people have created not only the main economic basis of their livelihoods but also the foundation of their lineages. The patrimonial dimension is locally acknowledged through the distinction between "inherited damar forests," transmitted following strict inheritance rules, from the first "planter" to the eldest son and so on, and newly created gardens that can be equally shared among children or even sold. Inherited damar forests are managed by the family patrimony holder for the benefit of all the living members of the lineage. Over the last century, these lineage forest patrimonies have allowed local people to achieve quite acceptable levels of economic development and social peace (Michon et al. 2000).

However, in the mid 1990s, these local patrimonies became threatened by a dual patrimonial claims on damar forests carried out simultaneously by national forest authorities and the international conservation community. Before decentralization policies, which have been developed since 2003, forest lands in Indonesia were considered as "national forest domain" and managed as a national patrimony. A State Forest Domain was delineated and projects developed without taking into consideration local management systems and rights. After this delineation took place in the region, the damar lands appeared to be included in the State Forest Domain, partly under the category of "production forest" and partly as "conservation forest." Over the course of the 1980s and the early 1990s, the Indonesian State assigned damar lands to a logging company, but damar farmers managed to restrict the incursion of the timber loggers into their lands without any external support. Things changed when the Indonesian government decided to open the damar country to industrial oil-palm planters as part of the valuation strategy of its forest patrimony. At the same time, the international patrimonial agenda for tropical forests related to biodiversity conservation reached the damar 
country, with the reactivation by an international conservation organization of a "sleeping" national park, established for the protection of the highly endangered Asian tiger, Sumatran rhino, and Asian elephant, and partly overlapping with damar lands.

These combined threats boosted interactions among local people worried about the future of their agroforest, international scientists studying the original social-ecological relationship shaping the agroforest system, and an Indonesian NGO working for the recognition of local rights and practices. This cooperation initiated a movement of patrimonial reconstruction carried out by local actors with the support of the local NGO and the backing of scientific conclusions that presented the damar agroforest as a unique example of domestic forest combining economic and social qualities and allowing for the conservation of plant and animal diversity, including the Sumatran rhino. This patrimonial reconstruction provided complementary social-ecological meaning to existing lineage patrimonies. It also modified the scale of patrimony definition. Although still local, the patrimonialized agroforest moved from a common good defined and managed at a lineage scale to a collective good legitimized over all damar lands at the scale of the whole damar community and its supporters.

This patrimonial movement was successful in combatting the double threat: by the end of 1990s, the social-environmental value of local agroforest patrimonies and the legitimacy of rights and claims attached to them by their local holders were officially acknowledged by the Indonesian government, and the agroforest (ecosystem and incorporated practices) was considered as an important addendum to the regional conservation system. Moreover, part of the international conservation community is now aware of-and charmed by - the special nature of agroforests in general which, aside from sheltering high levels of forest biodiversity, provides habitat for the above-mentioned endangered species. Through this double recognition, the damar agroforest, besides being regionally acknowledged and preserved because of its intrinsic qualities, also became an emblematic example of a local forest patrimony for higher scales: the Indonesian Ministry of Forestry publicized it as an essential contribution to the global "customary forest patrimony" of Indonesia and considered it as an emblematic example of what could be a "world indigenous agroforest heritage."

This latter example shows how far contemporary patrimonial constructions address the relationship between local and extralocal. Defining what is included in this relationship, translating local configurations into terms that can be understood by others but without conforming to all their norms and expectations, introduces a break between what was formerly defined "internally" as a patrimony and what is redefined in order to address this local/extra-local relationship.
These two examples also show that the success and consequences of patrimonialization depend on whether actors are also holders and beneficiaries of the patrimonial movement, and the patrimonialization process is based on existing situation, which usually happens when constructions develop at the local level. With more exogenous movements (national and international scales), there is a danger for the patrimonial movement to be disconnected from the concrete situation of concerned resources, spaces, and populations. Who exerts control over the definition of the patrimonial objects? What links them to their holders? Who evaluates them? What place is given to negotiation and deliberation? These are important questions to consider, in which the definition and the expression of legitimization are essential.

\section{DISCUSSION}

\section{Cross-Scale Patrimonialization: Beyond "Endogenous" and "Exogenous"}

As shown in these two examples, patrimonial dynamics develop at various scales, from diverse actors and perspectives, associated with different practices, institutions, and traditions, which treat forest in very different ways. Each of these perspectives on forests constructs patrimony rather differently.

These patrimonial visions, management regimes, and recommendations can be quite divergent, not only across scales from local to global, but, as Cormier-Salem suggested, between "endogenous" and "exogenous" processes. Local forest patrimonies are social-ecological systems that have evolved over the course of history from close overlaps between local practices and natural dynamics as shown for argan and damar forests. Even though this historical process does not explicitly refer to "patrimony," its patrimonial dimension can be analyzed retroactively as it contributes to maintaining the identity and autonomy of the social-ecological system as a whole. Present endogenous and often explicit patrimonial (re) constructions (like in the damar forest, or chestnut (Castanea sp.) forests in France; Michon 2011), are action-oriented processes that have different social or political objectives, but they usually have the same objective concerning socialecological relationships. Conversely, exogenous patrimonial processes introduce a disruption in this social-ecological integrity as they focus on objects (species, ecosystems, or landscapes) that hold a specific value at the global level and oversee locally evolved representations and practices that maintain them. Moreover, exogenous patrimonialization often does not acknowledge endogenous processes (especially historical ones) as valid patrimonial constructions. These exogenous processes, and the way they treat pre-existing patrimonies, can lead to the weakening of the latter, without strengthening other patrimonial dimensions at higher scales: endogenous patrimonial constructions in the argan forest have consolidated the argan oil market chain and industry-and, 
therefore, benefited extra-local oil processors-but erased local social-ecological relationships from which this product is derived and, therefore, threaten the identity and autonomy of the social-ecological system. The international patrimonial movement in the damar lands could have failed by disassociating the forest ecosystem from the practices that sustain its reproduction.

The interaction between patrimonial processes and their analysis from a patrimonial point of view may be divergent. Patrimonialization as an action-oriented process initiated at a given scale may not necessarily lead to patrimony construction from an academic - social and anthropological-point of view, as is shown in the argan development. Conversely, local patrimonialization processes (either historical or newly evolved), although highlighted in an academic perspective, can remain "invisible" and not get patrimonial recognition at the global level: the historical argan or damar patrimonies have long been (for damar) or still are (for argan) discounted at national or international levels, and the damar patrimony reconstruction had difficulties in finding its audience and meeting its objectives.

However, examples also show that, for a given forest, overlapping patrimonial constructions, especially if they are conflicting, may initiate new processes that aim at modifying this cross-scale relationship about forests among the various patrimony holders. The consequences of these overlapping patrimonializations should, therefore, not only be analyzed through the lenses of existing conflicts, but also by looking at modifications introduced into this cross-scale relationship and their impacts on the dynamics of the social-ecological system, especially in terms of resilience.

\section{Forest Patrimony and Resilience}

Walker et al. (2004) and Folke et al. (2010) distinguish three characteristics for social-ecological systems (SES) trajectories: resilience, adaptability, transformability. In the case of forests, how does patrimonialization interfere with these characteristics?

Some authors have shown that strict endogenous forest patrimonialization may contribute to strengthened socialecological system resilience and adaptability (Auclair et al. 2011, Michon 2011). National patrimonial forest management has proved successful in maintaining and reproducing large tracts of high and dense forests over centuries, at least in Europe. But, in southern countries, this national patrimonial management of forest lands was the most important factor of transformability or local SES, with the collapse of many forestbased systems and the transformation of independent farmers into wage-laborers (see, e.g., Fried 2000).

What happens when a forest is the target of several distinct patrimonial projects? When what relates to patrimonial development for some is considered to be an impediment to development by others (agroforest and oil palm, for example)? When the hidden agendas of the various actors are incompatible? The argan forest example shows the relative adaptability of local management systems, and the damar case illustrates the possible compromises that can be established over time between diverging patrimonialization processes.

Beyond these case studies, we stress that, as resilience thinking, patrimonial approaches deal with the conceptualization and management of complex relationships between nature and humans, embodied in various social-ecological systems. Patrimony is not only a "bridge between past, present and future" (Pupin 2008). The concept of patrimony not only sets the theoretical conditions for long-term existence and evolution of the relationship between a patrimonial object and its holder, which is considered as a strategy for a community to ensure sustainability of its economy, its livelihood, and its identity. Through its dynamic and adaptive nature, patrimony also poses the question of the continuous transformation of the relationship between humans and nature over time. This question is essential where forests are concerned, as forest existence and sustainability within anthropomorphic landscapes depends on the maintenance of positive relationship between humans and trees, and the adaptive management of forest-related values, knowledge, practices, and rules. Whether at local or national level, keeping forest patrimonies alive has proven to be one of the conditions for resilience of forest social-ecological systems. All over the world, rural societies have managed and transmitted specific flexible forest structures and cultures in what can be seen as a win-win ecology (Rosensweig 2003) and current patrimonial constructions can be understood as strategies reinforcing the adaptive capacity of social-ecological systems facing perturbations in a rapidly changing world.

As the notion of patrimony is increasingly successful, inspiring numerous public policies, a number of questions are worth asking. To what extent are exogenous patrimonialization processes, carried out and sustained by government intervention, factors of resilience, adaptability, or transformability? Do they allow for economic, social, and cultural sustainability of local SES or do they conflict with local logistics and, therefore, threaten local resilience? How do they interfere with endogenous patrimonialization processes?

\section{Forest Patrimony and Collective Action}

Patrimonialization usually changes the status of the objects it targets: when family forest patrimonies are redefined as collective patrimonies, they do not lose their status, but are governed by higher interests and more collective rules. This is even more obvious when local patrimonies are rolled into global patrimonies in which they may lose their identity and their autonomy, as might happen for damar agroforests in the face of tiger and rhino conservation efforts. 
Through its projection into a collectively chosen future, patrimonial development explicitly integrates the link between social-environmental dimensions, sociopolitical relationships, and collective action. As in the socialecological systems theory, actors at various scales are constrained by the nature of their relationship to resource use and dynamics, but they also must face the interdependence of their strategies. The variety and interrelationship of actors' objectives regarding resource use and development at different scales bear potential for conflict as well as for negotiation, depending on the property rights and political power of each of the actors concerned. A patrimony is always a compromise rising from negotiated technical, environmental, and institutional rearrangements, which lead to a more or less global reinterpretation of tradition, history, and culture. Discussion of collective values incorporated into patrimonies has the essential function of creating or reinforcing social links and solidarity among stakeholders.

The relationship to external stakeholders is also more and more essential in patrimonial development. The image of the argan forest as a unique Berber lineage revealing secrets of nature and Berber women was tailored to fit the expectations of cosmetic consumers in Europe. The image of global tropical forest patrimonies as endangered wildernesses also conforms to the conceptions of a distant civil society alarmed by the extinction of exotic animals and plants.

\section{Forest Patrimonies and Political Ecology}

The patrimony notion is generally presented as an effective and consensual tool to counter the privatization and monopolization of resources. It refers especially to the notion of common good. But, examples show that patrimonial constructions often incorporate a strong political dimension and can, therefore, be highly controversial or conflicting (Cormier-Salem et al. 2002, Michon 2011). And on behalf of patrimony, new forms of monopolization and exclusion can be established, as exemplified in the argan forest where the benefits of oil production are presently accruing to private processing and export firms.

Moreover, the political dimension of forest patrimonialization at all scales, although not highlighted by its promoters, is obvious.

Patrimonial construction, transmission, and destruction at local scales are necessarily influenced by higher-scale public policies, as discussed for the relationship between oil-palm expansion and agroforest dynamics in Indonesia. This also holds true at the national level, especially in developed countries where the capacity of states to sustainably manage the nation's collective forest patrimony is questioned by the international community. States, therefore, slowly switch from a sector-based management to a multipurpose management that integrates a strong environmental dimension. The national forest patrimony, therefore, has to be a resource able to fulfill the requirements of economic development and a space protecting global environmental issues.

But patrimonial constructions are also political acts in themselves, which may either crystallize or loosen tensions between local, national, and international levels because actors tend more and more to establish actions (identity claims, territorial or resource appropriation) that potentially go beyond their original declared purpose (conservation or transmission). Patrimonial dimension at the national level has legitimized authoritarian policies evicting farmers, considered as threats to the ecosystem, form the state forest domain in the name of public interest (Fay and Michon 2005). At the local level, the challenges of patrimonial development are to ensure better acknowledgment of their rights (including civic and political rights) by the ruling elites. Patrimony construction gives local communities better visibility and environmental credibility at international levels. It may allow them to establish new alliances with wider social, technical, and political networks and, therefore, break their historically difficult relationship with national sociopolitical hierarchies.

\section{CONCLUSION}

Patrimony is a trendy notion that presently inspires numerous local dynamics, national or international development projects, and public policies relating to nature management. Patrimonial claims involving natural elements all over the planet try to articulate local development logistics and strategies with global requirements for better environmental management and social development. Conventional patrimonies at domestic and national levels give way to patrimonial construction at local and global scales: applications to the world heritage are multiplying, whereas numerous local patrimonies are emerging in forest and agricultural areas, redefining the relationships not only between nature and society, but also among humans concerned with nature management. Beyond these processes, the concept of patrimonial management also offers new insights into natural resource management approaches, both from a theoretical point of view and from a more applied perspective.

But discussions about patrimony may appear confusing as the term may refer to an analytical concept or to concrete sociopolitical processes at various scales. Further confusion derives from the fact that the concept and the processes are constantly evolving. For the last 20 years, the scope of "patrimony" has moved from a rather narrow concept to embrace the complexity of the social-environmental relationship among nature, biodiversity, and local knowledge. Academic acceptance of patrimony has also switched from a definition centered on objects to a definition focused on relationships, incorporating intergenerational solidarity and collective action. Patrimonialization processes in natural resource management first referred to innovative action- 
oriented approaches developed by experts or policy makers in reaction to short-term state policies and their focus on technical intervention in environmental management. They were then initiated by a diversity of actors, starting from states to associations at various scales and local communities, for a variety of social-environmental objectives: biodiversity conservation, identity or territorial claims, resource appropriation, economic or cultural development. This multiplication of objects, actors, issues, and responsibilities on the resulting patrimonial scene, although difficult to correlate, offers new opportunities for theorizing and analysis of social-environmental relationships.

Responses to this article can be read online at: http://www.ecologyandsociety.org/voll7/iss3/art7/responses/

\section{Acknowledgments:}

This paper is partly based on a research funded by the French National Agency for Research, ANR.

\section{LITERATURE CITED}

Auclair, L., and G. Michon. 2009. La forêt rurale méditerranéenne entre deux paradigmes_étude comparée des constructions patrimoniales de l'arganeraie marocaine et de la châtaigneraie corse. Forêt Méditerranéenne 30(2):123133.

Auclair, L., R. Simenel, M. Alifriqui, and G. Michon. 2010. Agdal. Les voies imazighen de la patrimonialisation du territoire. Hespéris Tamuda 45:129-150.

Auclair, L., P. Baudot, D. Genin, B. Romagny, and R. Simenel. 2011. Patrimony for resilience: evidence from the forest Agdal in the Moroccan High Atlas Mountains. Ecology and Society 16(4): 24. [online] URL: http://dx.doi.org/10.5751/ES-04429 $\underline{-160424 /}$

Barthélemy, D., and M. Nieddu. 2007. Non-trade concerns in agricultural and environmental economics: how J.R. Commons and Karl Polanyi can help us. Journal of Economic Issues 41(2):519-527.

Calvo-Mendieta, I., O. Petit, and F.-D. Vivien. 2011, The patrimonial value of water: how to approach water management while avoiding an exclusively market perspective. Policy and Society 30(4):301-310. http://dx.doi. org/10.1016/j.polsoc.2011.10.006

Cormier-Salem M.-C., D. Juhé-Beaulaton, J. Boutrais, and B. Roussel. 2002. Patrimonialiser la nature tropicale. Dynamiques locales, enjeux internationaux. IRD éditions, Paris, France.
Cormier-Salem M.-C., D. Juhé-Beaulaton, J. Boutrais, and B. Roussel. 2005. Patrimoines naturels au Sud. Territoires, identités et stratégies locales. IRD éditions, Paris, France.

Descola, P. 2005. Par-delà nature et culture. Gallimard, Paris, France. http://dx.doi.org/10.3917/deba.114.0086

Doornbos, M., A. Saith, and B. White. 2000 Forests: nature, people, power. Blackwell Publishers, Malden, Massachusetts, USA.

Fay, C., and G. Michon. 2005. Redressing forest hegemony. Where a forestry regulatory framework is best replaced by an agrarian one. Forests, Trees and Livelihoods 15(2):193-210. http://dx.doi.org/10.1080/14728028.2005.9752520

Folke, C., S. R. Carpenter, B. Walker, M. Scheffer, T. Chapin, and J. Rockström. 2010. Resilience thinking: integrating resilience, adaptability and transformability. Ecology and Society 15(4): 20. [online] URL: http://www.ecologyandsociety. org/vol15/iss4/art20/

Fried, S. G. 2000. Tropical forests forever? A contextual ecology of Bentian rattan agroforestry system? Pages 204233 in C.Zerner, editor. People, plants, and justice: the politics of nature. Columbia University Press, New York, New York, USA.

Gillis, M. 1998. Indonesia: public policies, resource management and the tropical forest. Pages 43-114 in R. Repetto and M. Gillis, editors. Public policies and the misuse offorest resources. Cambridge University Press, Cambridge, UK and New York, New York, USA. http://dx.doi.org/10.1017/ CBO9780511601125.003

Handler, R. 1987. Heritage and hegemony: recent works on historic preservation and interpretation. Anthropological Quarterly 60(3):137-141. http://dx.doi.org/10.2307/3317633

Lazzarotti, O. 2003, Patrimoine. Pages 692-693 in J. Levy and M. Lussault. Dictionnaire de la géographie et de l'espace des sociétés. Belin, Paris, France.

Liu, J., T. Dietz, S. R. Carpenter, M. Alberti, C. Folke, E. Moran, A. N. Pell, P. Deadman, T. Kratz, J. Lubchenco, E. Ostrom, Z. Ouyang, W. Provencher, C. L. Redman, S. H. Schneider, and W. W. Taylor. 2007. Complexity of coupled human and natural systems. Science 317(5844):1513-1516. http://dx.doi.org/10.1126/science.1144004

Michon, G. 2011. Revisiting the resilience of chestnut forests in Corsica: from social-ecological systems theory to political ecology. Ecology and Society 16(2): 5. [online] URL: http:// www.ecologyandsociety.org/vol16/iss2/art5/

Michon, G., and H. de Foresta. 1999. Agro-forests: incorporating a forest vision in agroforestry. Pages 381-406 
in L. Buck, E. Fernandez and J. Lassoie, editors. Agroforestry and sustainable agroecosystems. CRC Press LLC, Boca Raton, Florida, New York, New York, and Washington, D.C., USA and London, UK.

Michon, G., H. de Foresta, A. Kusworo, and P. Levang. 2000. The damar agro-forests of Krui, Indonesia: justice for forest farmers. Pages 159-293 in C. Zerner, editor. People, plants and justice: the politics of nature conservation. Columbia University Press, New York, New York, USA.

Michon, G., H. de Foresta, P. Levang, and F. Verdeaux. 2007. Domestic forests: a new paradigm for integrating local communities' forestry into tropical forest science. Ecology and Society 12(2): 1. [online] URL: http://www.ecologyands ociety.org/vol12/iss2/art1/

Michon, G., and Sorba J. 2008. I tré valli. Passer par-dessus les montagnes. Ethnologie Française 38(3):465-477. http://d x.doi.org/10.3917/ethn.083.0465

Micoud, A. 2000. Patrimonialiser le vivant. Espaces Temps 74-75:66-77.

Micoud, A., and M. Peroni, editors. 2000. Ce qui nous relie. Editions de l'Aube, La Tour d'Aigues, France.

Nieddu, N., O. Petit, and F.-D. Vivien. 2009. Editorial: Identités, patrimoines collectifs et développement soutenable. Développement durable et territoires Dossier 12: Identités, patrimoines collectifs et développement soutenable. [online] URL: < a href="http://developpementdurable.revues.org/8126" target="_blank">http://developpementdurable.revues.org/8126

Ollagnon, H. 1979. Propositions pour une gestion patrimoniale des eaux souterraines : l'expérience de la nappe phréatique d'Alsace. Bulletin ministériel pour la rationalisation des choix budgétaires 36:33-73. La documentation française, Paris, France.

Ostrom, E. 1990. Governing the Commons. The Evolution of Institutions for Collective Action. Cambridge University Press, Cambridge, UK.

Perlin, J. 1997. A forest journey. The role of wood in the development of civilization. Harvard University Press, Cambridge, Massachusetts, USA.

Pupin, V. 2008. Les approches patrimoniales au regard de la question de la prise en charge du monde. Dissertation, AgroParistech, Paris, France. [online] URL: http://pastel.pari stech.org/4920/

Rosenzweig, M.L. 2003. Win-win ecology: how the earth's species can survive in the midst of human enterprise. Oxford University Press, New York, New York, USA

Simenel, R. 2010. L'origine est aux frontières. CNRS/MSH, Collège Les chemins de l'ethnologie, Paris, France.
Simenel, R., G. Michon, A. Auclair, B. Romagny, Y. Thomas, and M. Guyon. 2009. L'argan : l'huile qui cache la forêt domestique. De la valorisation du produit à la naturalisation de l'écosystème. Autrepart 50:51-74. http://dx.doi.org/10.3917/ autr.050.0051

Smouts, M. C. 2001. Forêts tropicales, jungle internationale: les revers de l'écopolitique mondiale. Presses de Science-Po, Paris, France.

Sourdril, A. 2008. Territoire et hiérarchie dans une société à maison bas-commingeoise : permanence et changement/ des bois, des champs, des prés (Haute-Garonne). Dissertation, Ecole doctorale Nanterre X, Nanterre, France.

UNESCO. 1972. Convention concerning the protection of the world cultural and natural heritage. UNESCO, Paris, France. [online] URL: http://whc.unesco.org/en/conventiontext

Vivien, F.-D., 2009. Pour une économie patrimoniale des ressources naturelles et de l'environnement. Mondes en développement 37(145):17-29. http://dx.doi.org/10.3917/med $\underline{.145 .0017}$

Walker, B., C. S. Holling, S. R. Carpenter, and A. Kinzig. 2004. Resilience, adaptability and transformability in socialecological systems. Ecology and Society 9(2): 5. [online] URL: http://www.ecologyandsociety.org/vol9/iss2/art5/

Weber, J. 1996. Conservation, développement et coordination : peut-on gérer biologiquement le social ? Colloque panafricain « Gestion communautaire des ressources naturelles renouvelables et développement durable ». 24-27 June 1996, Harare, Zimbabwe.

Zerner, C., editor. 2000. People, plants and justice. The politics of nature conservation. Columbia University Press, New York, New York, USA. 